\title{
Kyphoplasty experience in an elderly
}

\author{
Yaşlıda kifoplasti deneyimimiz
}

Mert AKBAŞ, Haitham Hamdy SALEM, Bora DiNÇ, Bilge KARSLI

To the Editor,

Vertebral compression fractures due to osteoporosis are seen frequently. Osteoporotic compression fractures can cause severe pain, limitation of physical activities and impairment of quality of life. Kyphoplasty, a minimally invasive procedure, could be effective in many cases and can provide fast pain relief. ${ }^{[1]}$

In our case, a patient with a history of falling from a height of 8 months duration visited our pain clinic. Analgesics were administered together with physical therapy and facet joint injections with no improvement. Radiological examination of the patient showed collapse fracture of L2 and L4 vertebrae on top of severe osteoporosis.

Kyphoplasty was done via an L2 transpedicular approach. Balloon was inflated until the anterior vertebral body height and kyphotic angle was notably corrected then $4 \mathrm{ml}$ polymethylmethacrylate cement was injected slowly. There was no any cement leakage or clinical complications. L4 vertebra was not intervened due to its introverted angle (Fig. 1, 2).

Post-operative radiological examination confirmed that kyphoplasty procedure was successful with correction of kyphotic angle and vertebral height. The patient's VAS pain score reduced from 8 to 3 and no pain medication was prescribed for the patient.

Kyphoplasty, a minimally invasive procedure for osteoporotic vertebral compression fracture shows promising results both in fast pain relief and low

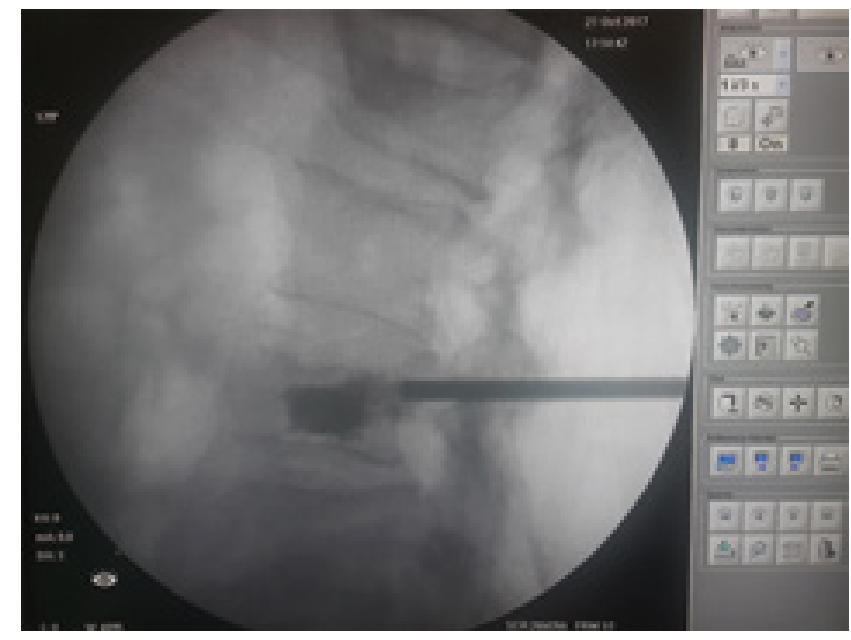

Figure 1.L2 transpedicular approach and polymethylmethacrylate cement injection.

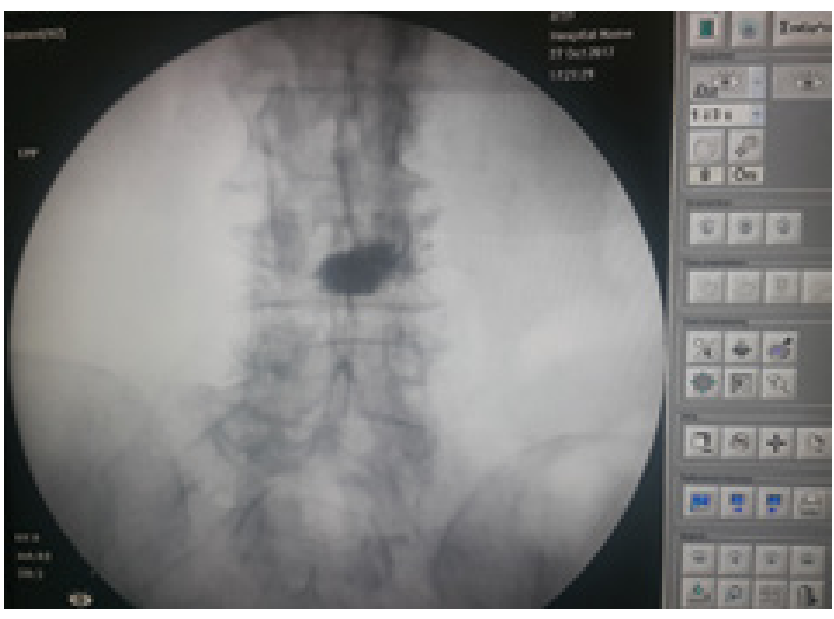

Figure 2. Radiological examination of the approach.

complication rates. ${ }^{[2,3]}$ Lange et al. found that after a 5-year follow-up of patients with osteoporotic vertebral fractures, mortality risk was much higher in medically treated patients compared to the pa-

Division of Algology, Department of Anesthesiology Reanimation, Akdeniz University Faculty of Medicine, Antalya, Turkey

Submitted: 03.12.2018 Accepted after revision: 04.08.2019 Available online date: 30.10.2020

Correspondence: Dr. Mert Akbaş. Akdeniz Üniversitesi Tıp Fakültesi, Anesteziyoloji Anabilim Dalı, Algoloji Bilim Dalı, Antalya, Turkey.

Phone: +90 - 242 - 2496257 e-mail: akbasmert@akdeniz.edu.tr

(c) 2020 Turkish Society of Algology 
tients who underwent kyphoplasty. ${ }^{[4]}$ Moreover, Kyphoplasty was more cost-effective than long-term medical therapies. On the other hand, kyphoplasty technique showed fewer leakage rates compared to vertebroplasty. ${ }^{[4-6]}$

Percutaneous balloon kyphoplasty is a safe and effective procedure for the treatment of elder patient with osteoporotic vertebral compression fractures.

\section{References}

1. Ledlie JT, Renfro M. Balloon kyphoplasty: one-year outcomes in vertebral body height restoration, chronic pain, and activity levels. J Neurosurg 2003;98(1 Suppl):36-42.

2. Czerwiński E, Zemankiewicz S, Osieleniec J. Kyphoplasty and vertebroplasty in the treatment of osteoporotic fractures of the spine. Ortop Traumatol Rehabil 2003;5(1):40-7.

3. Watts NB, Harris ST, Genant HK. Treatment of Painful Osteoporotic Vertebral Fractures with Percutaneous Vertebroplasty or Kyphoplasty. Osteoporosis International 2001;12:429-37. [CrossRef]

4. Lange A, Kasperk C, Alvares L, Sauermann S, Braun S. Survival and cost comparison of kyphoplasty and percutaneous vertebroplasty using German claims data. Spine (Phila Pa 1976) 2014;39(4):318-26. [CrossRef]

5. Taylor RS, Fritzell P, Taylor RJ. Balloon kyphoplasty in the management of vertebral compression fractures: an updated systematic review and meta-analysis. Eur Spine J 2007;16(8):1085-100. [CrossRef]

6. Chandra RV, Yoo AJ, Hirsch JA. Vertebral augmentation: update on safety, efficacy, cost effectiveness and increased survival? Pain Physician 2013;16(4):309-20. 